資 料

\title{
中心記憶課題ならびに偶発記憶課題における 選択的注意の発達的研究
}

\begin{abstract}
山 添
問題
\end{abstract}

選択的注意の研究は, Maccoby \& Hagen (1965), Hagen (1967) の 2 つの短期記憶刺激, 中心 - 偶発課題 (central- incidental memory task) を使った実験に始 まる。彼らは, 結果の解釈を行うために, Broadbent （1958）のフィルタ一理論を使用した。フィルター機制 とは, 選択的にある手がかりに注意し，他の手がかりを 無視することによって, 無視された情報は, フィルター を通過せずに記憶から消えてゆく，一方符号化された情 報は記憶に保持されて, さらなる処理のためにフィルタ 一を通過するといら事を指している。

続いて, Hagen \& Sabo (1967), Hagen \& Frish (1968), Druker \& Hagen (1969) は, 中心-偶発課題 の刺激特性の効果を探求するための実験を行った。結果 によると, 記憶課題遂行の発達的変化は, 刺激弁別では なく, 特定の符号化方略, 中心課題刺激の言語命名と焦

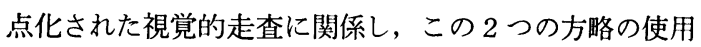
頻度は，年齢と共に高くなることを見出した。

ところで, Kendler \& Kendler (1962), Kendler (1963), Spiker (1963) など多くの研究者は, 媒介機制 を注意要因に加えて, 子どもの認知能力の重要な決定因 と考えている。Hagen \& Kingsley $(1968,1969)$ は, 短 期記憶遂行における実験者によって課された言語命名の 効果を探求したが，自発的にリハーサルをしない年少児 のみに，促進の効果がある事を明らかにした。また， Hagen, Meacham \& Mesibov (1970), Sabo \& Hagen (1971) は, 中心課題の遂行は, 年齢と共に発達しつづ けるが，それはリハーサルの使用と関係しており，この 方略は, 課された言語命名によって年齢増と共により多 く妨害される事を認めた。

Hagen \& Huntsman (1971) は, 知能年齢と共に選 択的注意遂行む進歩することと施設に生活する遅滞児 が，家庭で生活している遅滞児よりも，選択的注意の遂

* 京都大学
行に劣ることを示した。

次に, 以上の研究の問題点を指摘する。Hagen(1967) は, 実験の結果より, 中心課題遂行を維持するために, 偶発的情報を無視する能力は年齢と共に発達してゆくと 結論している。しかし, 広範囲の年齢にわたって, 偶発 学習の発達的研究を行った Siegel \& Stevenson (1966) は, Hagen の言うように, 偶発学習は年龄と共に単 調 に増大するのではなく，ある年龄まで増大するが，それ 以後は減少する弓形曲線を描くことを明らかにした。従 って, Hagen の年齢と偶発学習についての発達的見解 は，そのまま受け入れることは出来ない。

第 2 に, Hagen は, 最近の論文 (1972) で, 中心課 題遂行は, 単に記憶範囲に依るものではなく, 発達と課 題遂行に適した方略の関数として变化すると述べてい る。ところで Stevenson (1972) は，子どもは必ずしも 実験者の教示通り課題を遂行しているとはかぎらないと 主張している。従って, 中心課題遂行の含味には, この 教示の理解と使用の变数を統制した実験が必要とされる であろう。

第 3 に, Hagen \& Huntsman (1971) の実験は, 知 能年齢と共に選択的注意遂行も発達することを示してい る。しかし，Hagen らは既存の知能検査との関係をみ ているだけで，どのような知的活動と関係するのかとい ら分析を欠いている。

\section{実 験 I}

\section{目的}

年齢と選択的注意の関倸を検討する。特に，次の 2 点 を明らかにしたい。(1)年龄増と共に, 中心課題と偶発課 題の学習量の差（選択的注意）は大きくなるだろらか。 (2)また, 偶発課題の学習量は, ある年齢まで増大し, そ れ以後減少する弓形曲線のグラフを描くだろうか。

方法

材料 : 中心一偶発課題のために, 6 枚のたて $10 \mathrm{~cm}$, よこ $15 \mathrm{~cm}$ の提示カードPを使った。各カードには黒マ 
$P$
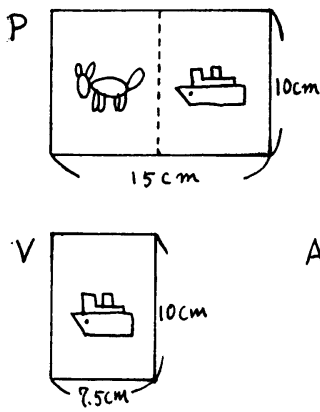

FIG. 1 本実験の材料

ジックインキで左側に動物が右側に乗物の絵が並べて書 かれている。例示用カードには，ネコーフネ，6枚の刺 激は，1）リスーロープウェイ，2）イヌーケーブルカー, 3）サルーシンカンセン，4）シカーサンリンシャ，5） ウシーヒコーキ，6）ウマージドウシャ。また中心課題 のために動物カード $\mathrm{A}(1 \sim 6)$ を手がかり用に用意す る。偶発課題のために乗物カード $\mathrm{V}(1 \sim 6)$ と動物カ 一ド $\mathrm{A}^{\prime}(1 \sim 6)$ をそれぞれ用意する。

手続： 6 枚の提示カードPを被験者の左より順に 1 ・ 2 ・ 3 と並べ，4 1 の上に置いて右に 5 ・ 6 と配り 2 列に並べる。例示カードは 1 のカードの左に置く。カー ドは全て裏返しておく。

中心課題 - 被験者は 1 人ずつ実験室に入る。実験者 （E）は「カード遊びをやってもらいます」といって始 める。例示カードを表向きにして被験者（S）に見せな がら「ここにある 6 枚のカードは，この例示カードと同 ビように，皆動物と乗物の絵が並べて書いてあります。 全て違ら絵が書いてあります。今から 1 枚ずつ見てもら いますが，動物だけが大切ですから，動物によく注意し て，どのカードにどんな動物が書いてあるか覚えて下さ い。乗物は見なくても覚えなくてもよろしい。後で私

（E）が『こんな（カードA) 動物はどのカードに書い ていましたか』と質問しますから，あなた（S）は，そ の動物を書いてあったカードをこのように（Eが実演） 手で押えて下さい。」例示カードで練習後, 例示カード と同じ絵を捜すのではなく, 個々のカードの絵を記憶す るのであることを理解しているかどうかを確認後に始め る。各カード 5 秒提示し, 次のカード提示までに 5 秒を おく。提示方法はカード1)から6)まで順番に行らが, 動 物手がかりの提示順序は，3）・5）・1）6）・2）・4）であ る。

偶発課題 - 被験者に乗物カードV、をわたしておく。 「最初みてもらったカード（P）には（例示カードを見 せて）このように動物と乗物が並べて書いてあったでし
TABLE 1 被験者のうちわけ

\begin{tabular}{c|c|c|c|c}
\hline \multicolumn{2}{l|}{} & 4 才群 & 6 才群 & 8 f群 \\
\hline \multirow{2}{*}{ 人 数 } & 男 & 10 & 10 & 10 \\
& 女 & 10 & 10 & 10 \\
\hline \multirow{2}{*}{ 平 均 年 齢 } & $4 ; 3$ & $6 ; 7$ & $8 ; 6$ \\
\hline
\end{tabular}

TABLE 2 中心課題得点の年齢別平均と S D

\begin{tabular}{cc|c|c|c}
\hline & & \multicolumn{2}{|c}{ 年 } & \multicolumn{2}{c}{ 齢 } \\
\cline { 3 - 5 } & & 4 & 6 & 8 \\
\hline 人 & 数 & 20 & 20 & 20 \\
平 & 均 & 2.10 & 3.95 & 5.48 \\
$\mathrm{~S}$ & $\mathrm{D}$ & 1.37 & 1.91 & 1.53 \\
\hline
\end{tabular}

TABLE 3 偶発課題得点の年齢別平均と S D

\begin{tabular}{cc|c|c|c}
\hline & & \multicolumn{2}{|c|}{ 年 } & \multicolumn{2}{c}{ 桧 } \\
\cline { 3 - 5 } & 4 & 6 & 8 \\
\hline 人 & 数 & 20 & 20 & 20 \\
平 & 均 & 1.70 & 1.65 & 1.19 \\
$\mathrm{~S}$ & $\mathrm{D}$ & 1.42 & 1.19 & 1.67 \\
\hline
\end{tabular}

よう。ところがここにあるカード（A／をランダムに 3 つずつ 2 列に並べる）には動物だけが書いてあります。 さあ，どの動物とどの乗物が並べて書いてあったかとい うことを思い出しながらやって下さい」と言い，また 「わかるものからやって下さい」旨の教示を与える。や り方がわからなければ，再度教示を与え，やり方を理解 させた後始める。中心，偶発課題いずれも制限時間 3 分 以内とする。

被験者: A幼稚園 4 才児および 6 才児。O 小学校 3 年 生 8 才児。被験者を TABLE 1 のように分けて実験を行 5 。

実験期日：1973年 3 月から 5 月,

\section{結果と考察}

TABLE 2 は年齢別の中心課題の得点の平均と S D 示している。 8 才の子どもの得点が一番高い。中心課題 得点は年齢と共に増大することを示している。 4 才と 6 才の平均の差は有意 $(t=3.43, p<0.01)$ であり, 6 才 と 8 才の間の平均の差む有意 $(t=2.73, p<0.05)$ であ る。

TABLE 3 は年齢別の偶発得点の平均と S Dを表わし ている。中心課題とは逆に, 偶発課題では 8 才の得点が 一番低く, 偶発課題得点は年齢と共に減少することを示 している。 4 才と 6 才の問の平均の差 $(t=0.119, p>$ $0.05)$ も 6 才と 8 才の差 $(t=0.978, p>0.05)$ もいず 
TABLE 4 選択的注意得点の年齢別平均と S D

\begin{tabular}{cc|c|c|c}
\hline & \multicolumn{2}{|c|}{ 年 } & \multicolumn{2}{c}{ 䶚 } \\
\cline { 3 - 5 } & 4 & 6 & 8 \\
\hline 人 & 数 & 20 & 20 & 20 \\
平 & 均 & 0.4 & 2.7 & 3.7 \\
$\mathrm{~S}$ & $\mathrm{D}$ & 2.1 & 1.7 & 2.28 \\
\hline
\end{tabular}

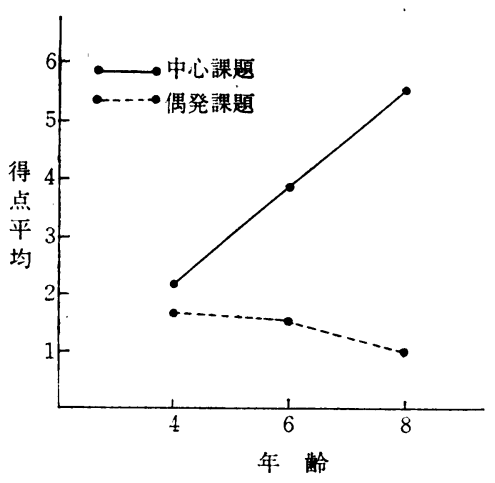

FIG. $14 \cdot 6 \cdot 8$ 才児の中心課題 偶発課題得点の平均值

れも有意でない。

TABLE 4 は Hagen の仮説を検証するためにつくら れた。つまり中心課題と偶発課題得点の差（選択的注意 得点）が各年跉ごとに平均とS Dで示されている。この 得点は年齢増と其に一貫して増大している。4才と 6 才 の間の, 6 才と 8 才の間の平均の差はそれぞれ $t=3.73$, $p<0.01 . t=2.38, p<0.01$ でいずれも有意である。 この結果を図示すると FIG. 1 のようになる。以上の結 果より (1)の仮説は認められたといえよう。しかし (2)の関 倸は見出されなかった。従って, 年齢と共に, 中心課題 遂行が有意に高くなり, 選択的注意能力は発達すること が認められた。また質問結果によると，8才児の典型的 な反応は次の通りである。偶発課題に対する内省を求め た時「わからない……」「おぼえなくていいといったか ら,おぼえていないの。」と答え, 彼らは課題遂行にお いて実験者の教示を自発的に利用し，教示に忠実な課題 遂行を示し，年少児より能率的な課題遂行を行っている ようである。

\section{実 験 II}

\section{目的}

課題遂行の方法の教示が理解されている時に, 課題の 遂行の困難度に違いがあると, 記憶範囲と選択的注意の 関係にどのような発達的変化がみられるかを, 中心課題 遂行の検討に焦点をあてながら，明らかにしたい。

\section{方法}

鈴木ビネー式知能検查項目である順唱と逆唱検査を使 用する。順唱は, 記憶範囲の典型的な検査方法である。 また同じく記憶範囲の検查ではあるが逆順序再生とい う, 順唱にくらべ, ひとつ操作が加わる逆唱は, その操 作のため, 課題遂行が困難になるので, 同範囲の時は, 逆唱の方がより高い知能年齢の課題になっている。

材料 : 数字が材料。順昌用には, 各範囲に次の材料を 用いる。 2 枌: $97 \cdot 27,3$ 桁 : 472 ・916, 4 桁: 9187 ・ 3629,5 析 $31759 \cdot 42385,6$ 析 $374859 \cdot 521746,7$ 析 : $2183465 \cdot 9728475,8$ 桁: $72534896 \cdot 49857362,9$ 析 : $596138274 \cdot 925841736$ 。次に逆唱材料は以下の通り。2 桁: $75 \cdot 26,3$ 枌: $945 \cdot 283,4$ 妳: $6528 \cdot 4937,5$ 桁 $: 31879 \cdot 96482,6$ 桁 : $471972 \cdot 583294,7$ 桁 $: 4162593$ - 3826475

手続：順唱「今，私（実験者）が数を読みますから 私が読み終ったら，今度はあなた（被跧者）が，私のい った通りに言って下さい。」順唱は各範囲に対して 2 試 行が許され，半分以上でもって合格とする。施行要領は 鈴木ビネーの個別検查による。逆唱,「私がまた数字を 読みますから，あなたはそれを逆にして言って下さい。 例えば，私が『1・2』と言ったら，あなたは『2・1』 と言うのです。それでは練習しましょう。『2・4』と言 ったら何と答えますか。」陦ねて被験者がやり方を理 解してからはじめる。順唱得点が 6 以上の被験者を高位 群に，5以下を低位群に分ける。逆唱の場合は 4 以上を 高位群に 3 以下を低位群に被験者を分ける。

被験者: $\mathrm{O}$ 小学校 1 年生 ( 6 寸児)と 3 年生 ( 8 才児), 各年齢20名, 計 40 名。なお選択的注意検查は実験 I に同 じ。

実験期日：実験 I に同じ。

\section{結果と考察}

各年齢の順唱, 逆唱の得点別人数が TABLE 5 に示さ れている。この結果を基にして, 前述した基準に従って 分類した順唱高位群と低位群の選択的注意得点の平均と

TABLE 5 各年齢の順唱・逆唱得点別人数表

\begin{tabular}{|c|c|c|c|c|c|c|c|c|c|}
\hline \multirow{3}{*}{ 順 } & \multirow{3}{*}{ 唱 } & 年齢 & 籁因 & 4 & 5 & 6 & 7 & 8 & 9 \\
\hline & & 6 & 才 & 3 & 10 & 3 & 4 & 0 & 0 \\
\hline & & 8 & 才 & 2 & 6 & 7 & 3 & 2 & 0 \\
\hline \multirow{3}{*}{ 逆 } & \multirow{3}{*}{ 唱 } & 年齢 & 範西 & 0 & 1 & 2 & 3 & 4 & 5 \\
\hline & & 6 & 才 & 1 & 0 & 6 & 9 & 4 & 0 \\
\hline & & 8 & 才 & 0 & 0 & 0 & 8 & 12 & 0 \\
\hline
\end{tabular}


TABLE 6 各年齢の順唱高低位群の選択 的注意の平均と.S D

\begin{tabular}{|c|c|c|c|c|c|}
\hline \multirow{2}{*}{ 順 } & \multirow{2}{*}{ 唱 } & 6 & 才 & 8 & 才 \\
\hline & & 中心課題 & 偶発課題 & 中心課題 & 偶発課題 \\
\hline 高 & 平均 & 3.62 & 1.38 & 5.38 & 1. 63 \\
\hline 位 & S D & 1.90 & 1.08 & 1. 11 & 2.06 \\
\hline 群 & 人数 & 13 & 13 & 8 & 8 \\
\hline 低 & 平均 & 2. 86 & 1.71 & 4. 58 & 1.17 \\
\hline 位 & S D & 1.73 & 1. 23 & 1.71 & 1.57 \\
\hline 群 & 人数 & 7 & 7 & 12 & 12 \\
\hline
\end{tabular}

TABLE 7 順唱 $\times$ 年齢 $\times$ 注意についての分散分析

\begin{tabular}{|c|c|c|c|c|c|c|c|}
\hline 変 & 動 & 因 & 平方和| & 自由度 & $\begin{array}{l}\text { 平均 } \\
\text { 平方 }\end{array}$ & $F$ & $P$ \\
\hline \multicolumn{3}{|c|}{ 記憶（順唱） } & 0.35 & 1 & 0.35 & 1. 29 & - \\
\hline \multicolumn{3}{|c|}{ 年 齢 } & 1.26 & 1 & 1.26 & 4.66 & $*$ \\
\hline \multicolumn{3}{|c|}{ 注 意 } & 13.88 & 1 & 13.88 & 51.41 & $* *$ \\
\hline \multicolumn{3}{|c|}{ 記憶 X年㱓 } & 0.55 & 1 & 0.55 & 2.04 & - \\
\hline \multicolumn{3}{|c|}{ 年齢×注意 } & 1.80 & 1 & 1.80 & 6.66 & ** \\
\hline \multicolumn{3}{|c|}{ 注意×記憶 } & 0.26 & 1 & 0.26 & 0.96 & - \\
\hline \multicolumn{3}{|c|}{ 記憶 $\times$ 年齢 $\times$ 注意 } & 0.23 & 1 & 0.23 & 0.85 & - \\
\hline \multicolumn{3}{|c|}{ 誤＼cjkstart差 } & 19.52 & 72 & 0.27 & & \\
\hline
\end{tabular}

**は $1 \%$ で有意。*は $5 \%$ で有意。

TABLE 8 各年齢の逆唱高低位群の選択 的注意の平均と S D

\begin{tabular}{|c|c|c|c|c|c|}
\hline \multirow{2}{*}{ 逆 } & \multirow{2}{*}{ 唱 } & 6 & 才 & 8 & 才 \\
\hline & & 中心課題 & 偶発課題 & 中心課題 & 偶発課題 \\
\hline 高 & 平均 & 2.94 & 1.25 & 4.00 & 1. 88 \\
\hline 位 & S D & 1. 82 & 1.03 & 1.80 & 1. 96 \\
\hline 群 & 人数 & 16 & 16 & 8 & 8 \\
\hline 低 & 平均 & 5 & 2.50 & 5.58 & 0.83 \\
\hline 位 & S D & 1.00 & 1. 12 & 0.86 & 1. 34 \\
\hline 群 & 人数 & 4 & 4 & 12 & 12 \\
\hline
\end{tabular}

TABLE 9 逆唱 $\times$ 年齢 $\times$ 注意についての分散分析

\begin{tabular}{|c|c|c|c|c|c|c|c|}
\hline 変 & 動 & 因 & 平方和 & 自由度 & $\begin{array}{l}\text { 平均 } \\
\text { 平方 }\end{array}$ & $F$ & $P$ \\
\hline \multicolumn{3}{|c|}{ 記憶（逆唱） } & 1.85 & 1 & 1.85 & 5.07 & * \\
\hline \multicolumn{3}{|c|}{ 年＼cjkstart龄 } & 0.04 & 1 & 0.04 & 0.11 & - \\
\hline \multicolumn{3}{|c|}{ 注 意 } & 15. 31 & 1 & 15.31 & 41.94 & $* *$ \\
\hline \multicolumn{3}{|c|}{ 記憶 $\times$ 年齢 } & 0.98 & 1 & 0.98 & 2.68 & - \\
\hline \multicolumn{3}{|c|}{ 年齢 $\times$ 注意 } & 0.94 & 1 & 0.94 & 2.58 & - \\
\hline \multicolumn{3}{|c|}{ 注意×記憶 } & 1. 48 & 1 & 1. 48 & 4. 05 & * \\
\hline \multicolumn{3}{|c|}{ 記憶 $\times$ 年路 $\times$ 注意 } & 0.36 & 1 & 0.36 & 0.99 & - \\
\hline 愦 & 奎 & & 26. 29 & 72 & 0.365 & & \\
\hline
\end{tabular}

**は $1 \%$ で有意 $*$ は $5 \%$ で有意
TABLE 10 選択的注意と順唱・逆唱範囲の 相関係数表

\begin{tabular}{cc|c|c}
\hline & & 注意と順唱 & 注意と逆唱 \\
\hline 6 & 才 & 0.19 & 0.23 \\
8 & 才 & 0.23 & 0.56 \\
\hline
\end{tabular}

標準偏差が TABLE 6 に示されている。この資料を分散 分析した結果が TABLE 7 である。年齢効果が $5 \%$ 水準 で, 選択的注意の効果が $1 \%$ 水淮で有意である。交互作 用は, 年齢 $\times$ 注意にのみ認められ， $1 \%$ 水淮で有意であ る。

逆唱の各年齢別の高・低位群の選択的注意得点の平均 と SDが TABLE 8 に, その分散分析が TABLE 9 に示 されている。逆唱についての分散分析の結 果は, 記憶 （逆唱）効果が $5 \%$ 水淮で, 選択的注意は $1 \%$ 水淮で有 意である。交互作用は，記憶 $\times$ 注意のみ認められた。

また, 最後の TABLE 10 は, 選択的注意と順唱, 逆 唱との相関係数を表にしたものである。それによると， 8 才児の逆唱得点と選択的注意得点のみが「有力な」相 関関係のあることを示している。つまり，逆唱に高い得 点を示す年長児は, 低いものよりも, 中心課題と偶発課 題の得点差 (選択的注意, 40 ペーシ参照) が, 大きく開 くことを示している。中心課題遂行得点の年龄は, 実験 I と同様認められたが, 記憶範囲との関係では, TABLE 9 の注意 $\times$ 記憶の交互作用の存在より, 逆唱記憶簕囲の. 上位の者は, 中心課題遂行にすぐれていることが示され ており，Hagen の主張と異なる結果がでている。

以上の結果より, 遂行の容易な課題に於ては, 選択的 注意は, 年齢と関係する記憶範囲には依らない。しか. し,より遂行の困難な課題に於ては, 遂行方法の教示の 理解・使用を統制すると, 前者の結果とは異なり, 年長 児に於てのみ, 記憶範囲と選択的注意との関係が認めら れる。

\section{実 験 III}

\section{目的}

知能年齢を同一にした時, 保存課題に対する反応と選 択的注意の間にどのような発達的関係があるか明らかに したい。

\section{A 実験}

知能検查・鈴木ビネ一個別式の実施により, MA 5 ・ 6・7才の児童を対象に選び, 更に次の保存実験を実 施。課題 1 ・ 2 は導入用。課題 1 ：「きのうお母さんか ら10時のおやつとしてアメ玉 4 つ(おはじきを並べる)， 3 時にも 4 つ。きょうも同じ数だけいただきました。き 
のうときょうはアメ玉同じだけ食べられますか。」

課題 2 ：「だけどきのらの10時はあんまりおなかがすい ていなかったので，その時は，アメ玉はたった 1 個しか 食べないで 3 時に他のアメ玉も全部一緒に食べることに しました。きのうと今日は同じだけ食べられますか。」 と言って, オ八ジキを移動させ, 昨日と今日のアメ玉の 数を判断させる。

課題 $3 \sim 5$ :オ八ジキ 6 個での多少等判断で変換は下図 の 3 種類である。

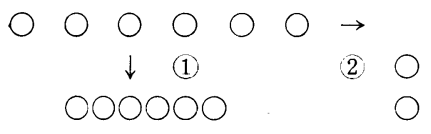

FIG. 2 課題 $3 \sim 5$ の変換

課題 6 ：「ちがう」という答には口頭でまたは指で「ど こがちがうか」を指摘してもらう。「同じ」といら答に 対しては「どこかちがうところはないか」と質問を重ね る。

\section{$\mathrm{B}$ 実験}

量の保存課題：ねん土を用意する。それを 2 つに等 分 し，まるくして被験者にそれらが同等であることを確か めた後で，一方を押しつぶして血型にし「これとこれ （皿形に変形したもの）にねん土は，同じだけあります か，それともちがいますかと質問する。被験者が「ちが ら」と答えた時には「それでは, これとこれでは, どち らの方が权ん土はたくさんありますか」と比較判断を求 める。次に円型変形も同じ手続で行う。

数の保存課題 : 上列 3 個, 下列 3 個のオ八ジキを並べ る。上列・下列を等しくならべて, 被験者に同等判断を
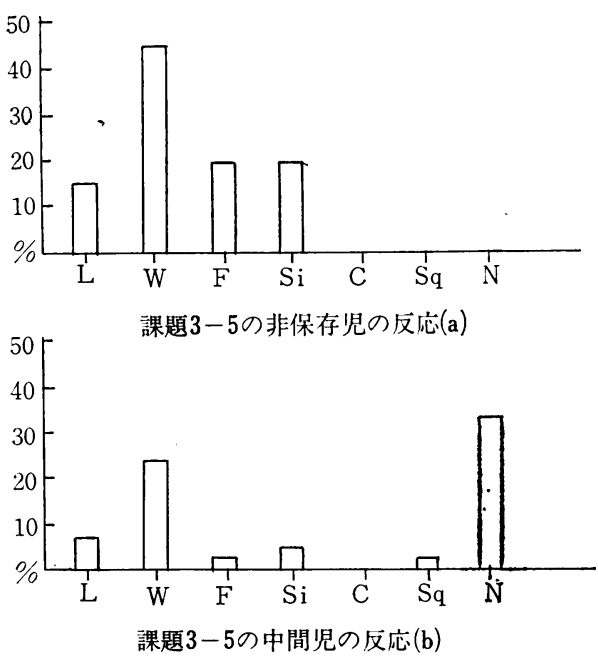

TABLE 11 各群の人数

\begin{tabular}{l|c|c|c}
\hline \multirow{4}{*}{ 人 数 } & \multicolumn{2}{|c}{ 反 } & \multicolumn{2}{|c}{ 応 } \\
\cline { 2 - 4 } & 保 存 & 中 間 & 非保存 \\
& 11 & 7 & 13 \\
\hline
\end{tabular}

TABLE 12 課題 3 5 における各群の各次元 に対する反応結果

\begin{tabular}{|c|c|c|c|c|c|}
\hline 资元 & 群 & 保 & 存 & 中 & 非保 存 \\
\hline 数 & $(\mathrm{N})$ & & 33 & 8 & 0 \\
\hline 長さ & $(\mathrm{L})$ & & 0 & 2 & 5 \\
\hline 幅 & $(W)$ & & 0 & 6 & 16 \\
\hline 形 & $(F)$ & & 0 & 1 & 9 \\
\hline 大きさ & $(\mathrm{Si})$ & & 0 & 2 & 9 \\
\hline 色 & (C) & & 0 & 0 & 0 \\
\hline 面積 & $(\mathrm{Sq})$ & & 0 & 2 & 0 \\
\hline 計 & & & 33 & 21 & 39 \\
\hline
\end{tabular}

求めた後，上列の幅を大きくして被験者に次の質問をす る。「うえ (上列) と下 (下列) のおはじきの数は同じ ですか，それともちがいますか。」「ちがう」と答えた時 「それでは，上と下はどちらが多いですか少ないです か」と発問を続ける。次に上列 5 個, 下列 5 個で上述し た同じ手続で保存実験を行う。

被験者: $\mathrm{A}$ 実験の被験者は, $\mathrm{F}$ 幼稚園坚31名で, 課題 $3 \sim 5$ を与えて, 全問正答を保存群に, 全問誤答を非保 存，その他を中閏群に分類する。

B実験では，MAを統制するために，被験者である F 幼稚園児60名に, 鈴木ビネ一式の個別検査を実施し, そ のうちMAが $5 \sim 8$ 才までのもの 57 名に，B実験用の保
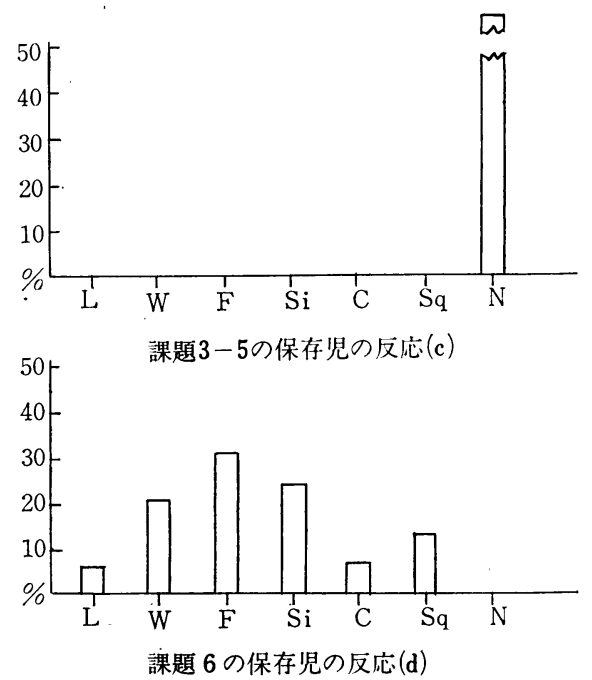

FIG. 2 課題に対する各群の児童の反応次元のパーセント 
TABLE 13 各課題に対するMA別の正答人数と通過率

\begin{tabular}{|c|c|c|c|c|c|c|c|c|c|c|c|c|c|c|c|}
\hline $\mathrm{M}$ & & 5 & & & 6 & & & 7 & & & 8 & & 合 & 計 & 平均 \\
\hline 課 題 & $\begin{array}{l}\text { 人 } \\
\text { 数 }\end{array}$ & $\begin{array}{l}\text { 正 } \\
\text { 答 } \\
\text { 数 }\end{array}$ & $\begin{array}{l}\text { 通 } \\
\text { 過 } \\
\text { 率 } \\
\%\end{array}$ & 数 & $\begin{array}{l}\text { 䇛 } \\
\text { 䇴 } \\
\text { 数 }\end{array}$ & $\begin{array}{l}\text { 通 } \\
\text { 過 } \\
\text { 率 } \\
\%\end{array}$ & $\begin{array}{l}\text { 人 } \\
\text { 数 }\end{array}$ & $\begin{array}{l}\text { 政 } \\
\text { 筌 } \\
\text { 数 }\end{array}$ & $\begin{array}{l}\text { 通 } \\
\text { 過 } \\
\text { 率 } \\
\%\end{array}$ & $\begin{array}{l}\text { 人 } \\
\text { 数 }\end{array}$ & $\begin{array}{l}\text { 正 } \\
\text { 答 } \\
\text { 数 }\end{array}$ & $\begin{array}{l}\text { 通 } \\
\text { 過 } \\
\text { 率 } \\
\%\end{array}$ & 数 & $\begin{array}{l}\text { 正 } \\
\text { 答 } \\
\text { 数 }\end{array}$ & $\begin{array}{l}\text { 通 } \\
\text { 過 } \\
\text { 率 }\end{array}$ \\
\hline $\mathrm{B}$ 血 $(1)$ & 20 & 10 & 50 & 19 & 7 & 37 & 16 & 9 & 56 & 2 & 0 & 0 & 57 & 26 & 46 \\
\hline $\mathrm{B}_{\text {円 }}$ - $(2)$ & 20 & 8 & 40 & 19 & 6 & 32 & 16 & 7 & 44 & 2 & 1 & 50 & 57 & 22 & 39 \\
\hline $\mathrm{C}-\frac{(1)}{3}$ & 20 & 8 & 40 & 19 & 12 & 63 & 16 & 10 & 63 & 2 & 0 & 0 & 57 & 30 & 53 \\
\hline $\mathrm{C}-\frac{(2)}{5}$ & 20 & 7 & 35 & 19 & 11 & 58 & 16 & 7 & 44 & 2 & 0 & 0 & 57 & 25 & 44 \\
\hline
\end{tabular}

TABLE 14 MA 5・6才児の数の保存・ 非保存群の課題別得点

\begin{tabular}{|c|c|c|c|c|c|}
\hline & $\mathrm{MA}$ & 5 & 扌 & 6 & 才 \\
\hline 保存 & 汪意 & 中心課題 & 偶発課題 & 中心課題 & 偶発課題 \\
\hline 保 & 存 & 19 & 9 & 25 & 8 \\
\hline 非 保 & 存 & 19 & 5 & 20 & 6 \\
\hline
\end{tabular}

TABLE 15 保存性の有無 $\times$ MA $\times$ 注意に ついての分散分析

\begin{tabular}{|c|c|c|c|c|c|c|c|}
\hline 変 & 動 & 因 & 平方和| & 自由度 & $\begin{array}{l}\text { 平均 } \\
\text { 平方 }\end{array}$ & $\mathrm{F}$ & $\mathrm{P}$ \\
\hline \multicolumn{3}{|c|}{ 保存（数） } & 2. 160 & 1 & 2. 160 & 1.117 & - \\
\hline \multicolumn{3}{|c|}{ MA } & 0.875 & 1 & 0.875 & 0.452 & - \\
\hline \multicolumn{3}{|c|}{ 注 意 } & 54.018 & 1 & 54.018 & 27.880 & $* *$ \\
\hline \multicolumn{3}{|c|}{ 保存 $\times$ MA } & $0.161 \mid$ & 1 & 0.161 & 0.084 & - \\
\hline \multicolumn{3}{|c|}{ MAX注意 } & 0.875 & 1 & 0.875 & 0.452 & - \\
\hline \multicolumn{3}{|c|}{ 注意×保存 } & 0.019 & 1 & 0.019 & 0.010 & - \\
\hline \multicolumn{3}{|c|}{ 保存 $\times$ MA $\times$ 注意 } & 0.874 & 1 & 0.874 & 0.451 & - \\
\hline \multicolumn{3}{|c|}{ 誤＼cjkstart差 } & 93 & 48 & 1.938 & & \\
\hline
\end{tabular}

**は $1 \%$ で有意

存課題を与える。数・量課題の各 2 問正答を保存, 2 問 誤答を非保存群として分類する。

\section{結果と考察}

A 実験について, 各群の人数が TABLE 11 に, 各群 の各反応次元に対する合計が TABLE 12 に示されてい る。各群の合計で各次元反応数を割ったパーセントがグ ラフで FIG. 2 に示されている。(a)(b)と(d)を比較すると 分るように保存児童は他群の児童より多次元に反応する ことが可能であり，また(c)によると課題に不適切な次元 を無視できる能力をもっている。

B実験について, 各 MA 児童の課題別正答率が,

TABLE 13 に示されている。この表に従って使用した
TABLE 16 MA $5 \cdot 6$ 才児の量の保存・ 非保存群の課題別得点

\begin{tabular}{|c|c|c|c|c|c|}
\hline & $\overline{M A}$ & 5 & 才 & 6 & 才 \\
\hline 保存 & 注意 & 中心巣题 & 偶発課題 & 中心課題 & 偶発課題 \\
\hline 保 & 存 & 26 & 8 & 28 & 9 \\
\hline 非 保 & 存 & 15 & 10 & 22 & 12 \\
\hline
\end{tabular}

TABLE 17 保存性の有無 $\times$ MA $\times$ 注意に ついての分散分析

\begin{tabular}{|c|c|c|c|c|c|}
\hline 変＼cjkstart動 & \multicolumn{3}{|c|}{ 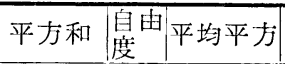 } & $F$ & $P$ \\
\hline 保存（量） & 157.940 & 1 & 157.940 & 86.51 & $* *$ \\
\hline MA & 2.250 & 1 & 2.250 & 1.23 & - \\
\hline 注 意 & 42.250 & 1 & 42.250 & 23. 14 & $* *$ \\
\hline 保存 $\times$ MA & 0.565 & 1 & 0.565 & 0.31 & - \\
\hline$M A \times$ 注意 & 0.565 & 1 & 0.565 & 0.31 & - \\
\hline 注意×保存 & 7.565 & 1 & 7.565 & 4. 14 & $*$ \\
\hline 保存 $\times \mathrm{MA} \times$ 注意 & 0.245 & 1 & 0.245 & 0.13 & - \\
\hline 誤＼cjkstart差 & 102.250 & 56 & 1.826 & & \\
\hline
\end{tabular}

**は $1 \%$ で有意 *は $5 \%$ で有意

課題の困難順を決定すると次のようになる。1 B-(2), $2 \mathrm{C}$-(2)，3 B-(1)，4 C-(1)。数・量別に分散をとる が, それは TABLE 13 の示すように量の課題の方がよ り困難であったためである。まず，MA 5 ・6才に於る 数の保存・非保存児の選択的注意の得点が TABLE 14 に示されている。この資料を分散分析した結果を示した のが TABLE 15 である。

次に数と同様量についての選択的注意の得点とその分 散分析の結果が, TABLE 16・17 に示されている。

数と量の分散分析の結果は, 両者では注意のみが有意 である。数の分散では主効果のみられたのは注意のみ で, 交互作用も認められなかった。しかし量の分散で 
は, 注意に主効果 $(p<0.01)$ が, 注意 $\times$ 保存の交互作 用において有意差 $(0.01<p<0.05)$ が認められる。実 験 $\mathrm{A}$ は保存児の注意の機制を明らかにしたが, 実験 $\mathrm{B}$ は, より困難な思考課題の遂行能力を持つものは, より 高い選択的注意を持つことを示している。

A 実験によると，保存児は多次元に注意することが可 能であるが, 反応は不適切次元を無視して適切次元での み行っている。非保存児は注意できる次元数が少なく， しかも自分に優位な次元に基づいてのみ, 直接的に反応 している。中間児は, 反応する時に, 不適切次元から適 切次元への「切り換え」に困難があると考えられる。従 って, 保存性の反応の発達は, 注意範囲 (次元数) の拡 大・次元間切り換え能力の発達を経て達成されると考え られる。B実験について，いわゆる「保存」実験では， 課題の選び方によって, 子どもの遂行得点が変わるの で, 課題の難易度の決定は大切である。そのための調查 （TABLE 13）によると，この実験で使用した課題で は, 量の保存の方が困難であった。分散分析の結果によ ると, 選択的注意は, より困難な課題の遂行と関係する ことが明らかにされた。

\section{結 論}

我々の 3 つの実験の結果によると, 子どもにとって, より困難な課題の遂行のために選択的注意は必要であ り，この記憶方略は年齢と共に発達し，8才以後に完成 すると考えられる。それ以前の年少児は，中心課題に注 意し，偶発課題を無視するという我々の課した教示を課 題遂行に利用することが困難である。

\section{<付記 $>$}

本稿は, 京都大学大学院教育学研究科に昭和 48 年度修 土論文として提出したものの一部に加筆したものであ る。本論文をまとめるにあたり御指導いただいた梅本堯 夫教授, 実験を手伝っていただいた大津市立晴嵐小学 校, 京都双葉幼稚園, 神大明石附属幼稚園の諸先生方,
園児；児童の皆さんにお世話になった。記して感謝の意 を表します。

\section{文献}

Hagen, J. W. 1967 The effect of distraction on selective attention. Child Development. 38, 685. $-694$

Hagen, J. W., Strategies for remembering. In Farnham-Diggory, S. (Ed.) 1973 Information processing in children. Academic Press.

Hagen, J. W. and Huntsman, N. J. 1971 Selective attention in mental retardates. Developmental Psychology, 5, 151-160

Hagen, J. W., and Kingsley, P. R. 1968 Labeling effects in short-term memory. Child Development, 39, 113-121

Hagen, J. W., Meacham, J. A., and Mesibov, G. 1970 Verbal labeling, rehearsal, and short-term memory. Cognitiv Psychology, 1, 47-58

Miller, P. H. 1973 Attention to stimulus dimension in conservation of liquid quantity. Child Development, 44, 129-136

Mostofsky, D.I. 1970 Attention : Contemporary and analysis. Appleton Century-Crofts.

Siegel, A.W., and Stevenson, H.W. 1966 Incidental learning: a developmental study. Child Development. 37, 811-817

Stevenson, H.W. 1972 Children's learning. Appleton Century-Crofts.

梅本堯夫編1969講座心理学 7 記憶 東大出版会 山添 正1970数概念の発達における言語教示の効果末発 表論文

(1975年 2 月 10 日受稿). 